\title{
PHARMACOEPIDEMIOLOGICAL ANALYSIS: DYNAMICS OF AVAILABILITY OF STATINS IN UKRAINE
}

\author{
N.V.Bezditko, L.V.Iakovlieva, O.Ya.Mishchenko, I.V.Chynush, E.L.Toryanik
}

\author{
National University of Pharmacy \\ Key words: pharmacoeconomics; statins; pharmaceutical market; range of drugs; dynamics; \\ coefficient of the solvency adequacy
}

\begin{abstract}
Diseases of the circulatory system are the main cause of disability and premature death in Ukraine. A great number of RCTs and meta-analyses proved high preventive efficiency of statins to reduce the cardiovascular risk. The aim of the study is to analyze the dynamics of cost and availability of statin drugs in Ukraine in 2012-2015. Dynamics of the prices for some statin drugs was determined according to the data of the "Pharmstandard" system of "Morion" company. To assess availability of the statin therapy the coefficient of the solvency adequacy was used. According to the results of the study it has been found that at the pharmaceutical market of Ukraine there is an adequate range of statin drugs. During the period from 2012 to 2015 there was the positive dynamics of the market structure -increase in domestic drug production and its share in the market structure. From 2014 there was the increase in prices for the vast majority of drugs of the statin group of both domestic and foreign production - the average for the group was $42.1 \%$ and $101.4 \%$, respectively. The dynamics of the solvency adequacy indicates decrease in availability of statin drugs for the Ukrainian consumers in the period from 2012 to 2015. Under these conditions the possibility of the primary and secondary prevention of CVD is provided by high economic availability of domestic generic drugs, which range over the past four years has increased by 38\%. Measures in the healthcare system, contributing to increase availability and the amounts of statin use in Ukraine are needed.
\end{abstract}

$\mathrm{D}$ iseases of the circulatory system are the main cause of disability and premature death all over the world. In Ukraine the number of deaths from diseases of the circulatory system, including coronary heart disease (CHD) and stroke, exceeded the number of deaths of all types of cancer, AIDS and tuberculosis taken together in 2012 [1, 2]. In 2014 the death rate from the circulatory system diseases was 676 persons per 100000 of the population. It is one of the highest rates in Europe [3].

The numerous epidemiological studies proved the role of hypercholesterolemia in morbidity and mortality of coronary heart disease [27, 32] and stroke $[4,9]$ over the last decade. The benefits of lipid reduction in the coronary artery disease were demonstrated in meta-analyses of the prospective controlled clinical trials concerning reduction of cholesterol; they included 65.000 patients who took the statin group of drugs [10, 22]. The meta-analysis of 24 published trials of the com- parative statin therapy with the control group, which included 165,792 persons, demonstrated that the statin therapy was associated with reduction in frequency of all strokes - primary and repeated, ischemic and hemorrhagic ones - approximately by onefifth $[9,16]$. These data formed the basis for application of the statin therapy as the primary strategy for reducing the risk of cardiovascular complications $[4,14$, 17]. The number of meta-analyses of the studies with statins included more than 170.000 cases and indicated the safety of therapy if these medicines were used $[23,24,31]$. The clinical studies of the past recent years confirm the high efficiency and safety of the statin therapy for patients with the risk factors [12, 13, 26, 28]. The positive effect of statins on the vascular state, which was not related to the effect on the lipid level, was also proven [11, 29]. Taking into account the high morbidity and mortality the primary and secondary statin prevention is indicated for the significant

N.V.Bezditko - Doctor of Medicine, professor of the Department of Pharmacoeconomics of the National University of Pharmacy (Kharkiv) segment of the population of Ukraine.

The real possibility of using statins in the clinical practice depends largely on availability of the appropriate drugs at the pharmaceutical market, their product range and affordability for the general population.

The aim of the work was to analyze the dynamics of the cost and economic availability of drugs of the statin group in Ukraine in 2012-2015.

\section{Materials and Methods}

Such research methods as logical, monitoring, system, and graphic were used. The analysis of the range and cost of domestic and foreign statin drugs was conducted on the basis of the data of the "Pharmstandard" system of "Morion" company [7]. The data on average wages were taken from the official website of the State Statistics Committee of Ukraine [3]. To assess economic availability of the statin therapy for the Ukrainian population the coefficient of the solvency adequacy was used. It shows the percentage of the average wage accounts for the cost of a course of treatment by a 


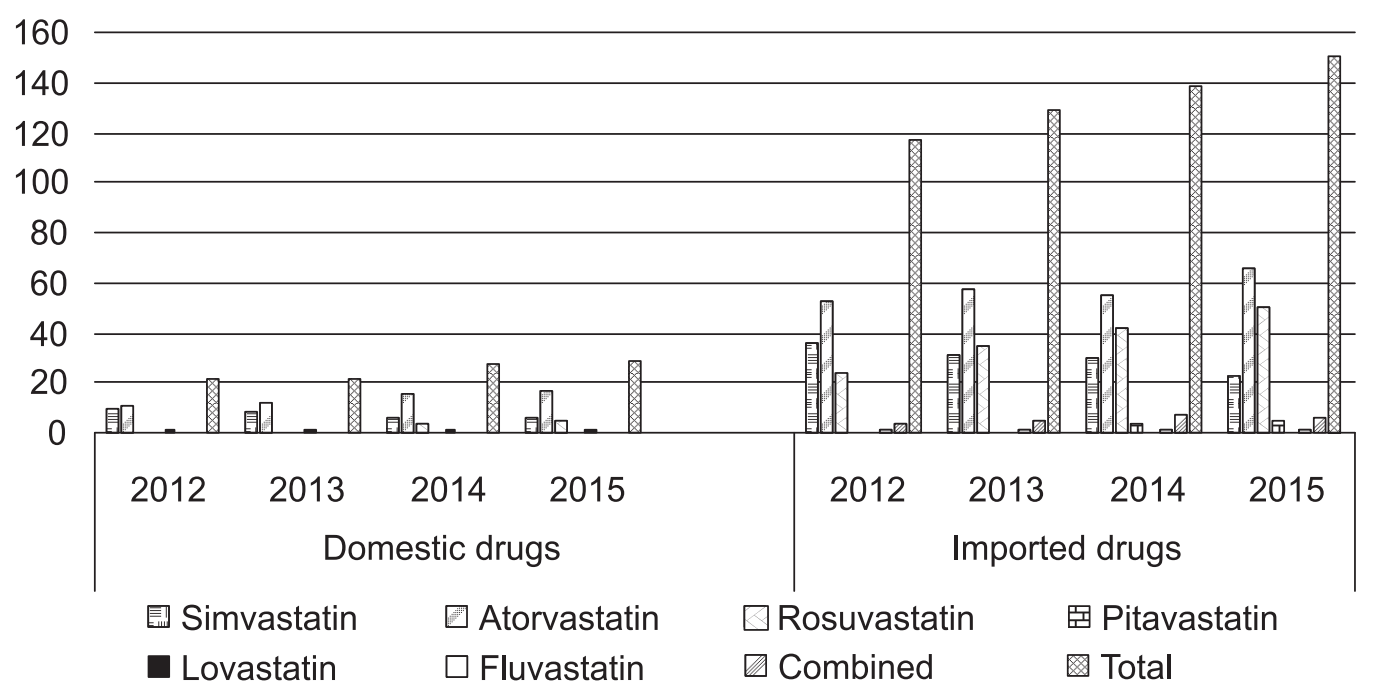

Fig. 1. The range of statin drugs at the Ukrainian pharmaceutical market in 2012-2015

specific drug and the solvency of the consumer. The lower the value of this indicator is, the greater availability of the drug is for the consumer $[5,6]$. This indicator was calculated only for those drugs, which were present at the market during the period of study, according to the formula:

$$
\text { Ca.s. }=(\text { Pav/Wa.w. }) \times 100 \% \text {, }
$$

where: Ca.s. - is the coefficient of the solvency adequacy;

Pav - is the average cost of a course of treatment by the drug for a certain period;

Wa.w. - is the average wage for a certain period.

The cost of one month of the treatment by each of the statins in the dose equal to DDD was taken as the cost of the course of treatment in this study. DDD is the standard average daily dose of the drug used according to the main indications in adults [15, 25]. DDD is as close as possible for the actual application and is derived on the basis of practical recommendations and reference sources, as well as the clinical experience of the drug use [18]. Calculating the cost of treatment using DDD allows to estimate approximately the real costs for drug treatment [8].

\section{Results and Discussion}

As of December 2015, taking into account the unit doses and dosage forms, at the Ukrainian pharmaceutical market there were 180 statin drugs (29 domestic and 151 imported ones) from 49 manufacturers (13 domestic and 36 foreign producers). From 2012 to 2015 the number of drugs of the statin group increased by $30.4 \%$. The range of the domestic drugs was greater than import ones (38\% and 29\%, respectively). Such drugs as atorvastin and rosuvastatin by two domestic producers were added to simvastatin and lovastatin available at the drug market. Nevertheless, the percentage of statins in the structure of the domestic market remains significantly less than the import drugs $(16.1 \%$ and $73.9 \%$, respectively). The largest growth of the range of drugs was recorded for rosuvastatin (129\%). The range of drugs of atorvastatin increased by $29.6 \%$, while simvastatin decreased by $35.6 \%$ (Fig. 1). In the randomized clinical trials conducted and the meta-analyses generalizing them it has been shown that by efficiency of reduction of CHD statins are divided in descending order as follows: rosuvastatin - atorvastatin - simvastatin $[19,20,21,30]$. In our opinion, the dynamics of the statin range at the Ukrainian pharmaceutical market should be assessed as positive.

Thus, the analysis carried out has indicated that statin drugs at the Ukrainian pharmaceutical market are presented in the sufficient range. During the period from 2012 to 2015 there was the positive dynamics of statin drugs: increase in domestic drug production and its share in the market structure, appearance of new domestic manufacturers of statins, the share increase of rosuvastatin drugs. Rosuvastatin is newer than simvastatin and atorvastatin with the proven efficacy and safety as a hypolipidemic drug.

In addition to the physical accessibility of drugs, the real possibility of pharmacotherapy to a large extent depends on their economic availability. The analysis of the dynamics of the prices for statin drugs indicated the following advantages. In 2013 as compared to 2012 there was $12-14 \%$ increase in price for $55 \%$ of domestic simvastatins, while the price for $44.6 \%$ of drugs became lower by $1.4-6.3 \%$. In 2014 the price reduction was for 3 of 10 domestic simvastatin drugs presented at the Ukrainian market. In 2015 these drugs were not presented at the market. The prices for all domestic simvastatin drugs left at the market in 2015 as compared to 2014 increased by $2.7-41.3 \%$. In general, over the period of 2012-2015 domestic simvastatins became more expensive by $33 \%$.

During the period analyzed the prices for domestic drugs of ator- 


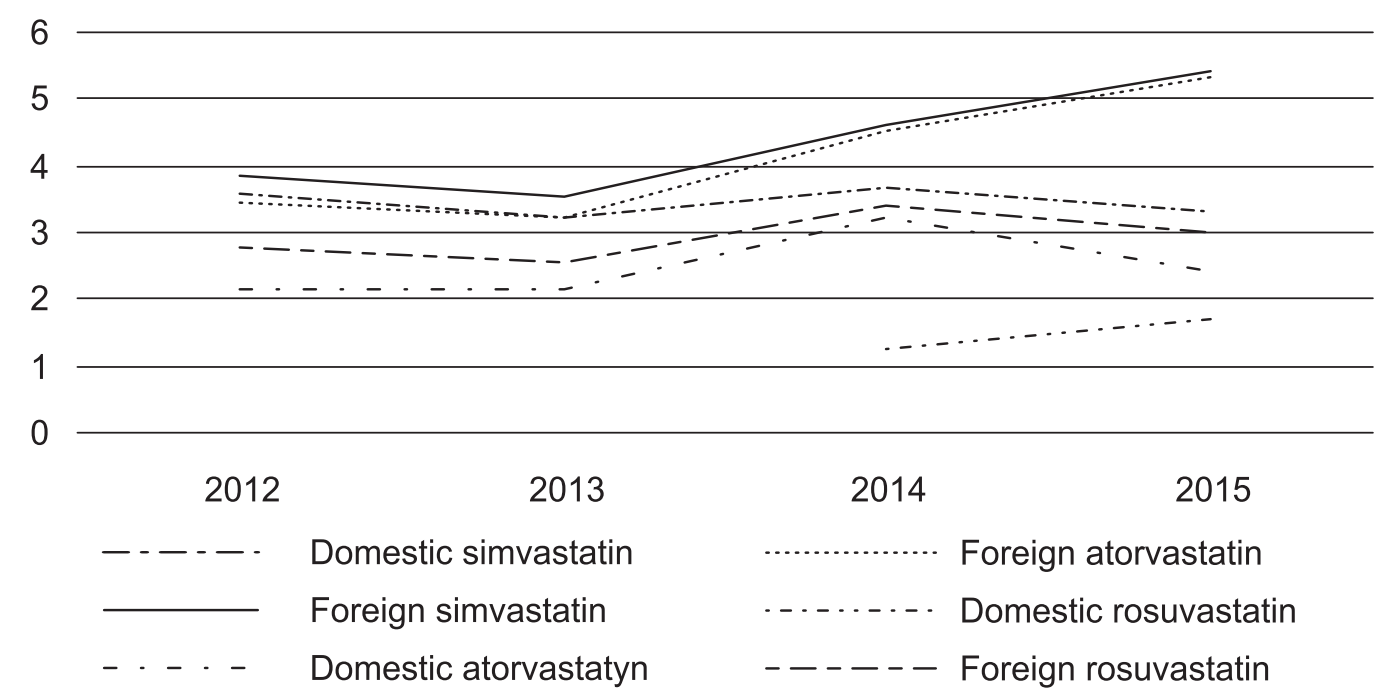

Fig. 2. The dynamics of the coefficient of the solvency adequacy (Ca.s) for statin drugs in the period from 2012 to 2015

vastatin have a clear tendency to increase: in 2013 from 2.5 to $25.8 \%$, in 2014 from 7.6 to 63.8\%, in 2015 from 10.2 to $30.0 \%$. Only one domestic atorvastatin drug (Vasocleen, film coated tablets, $20 \mathrm{mg}$, No.30, produced by “Darnitsa” JSC) reduced the price by 32\% in 2015 . In general, from 2012 to 2015 domestic drugs of atorvastatin became more expensive approximately by $43.9 \%$. The domestic rosuvastatin appeared at the market in 2014 and was presented only by four trade names of one manufacturer. In 2015 the price for these drugs increased from 29.4 to $104.9 \%$. In general, from 2012 - 2015 the prices for domestic statins increased on average by $42.1 \%$.

A clear trend to increase the average prices and the number of drugs, which price increases every year, is observed in the analysis of the market of statin drugs of foreign production. For example, in 2013 the price dropped from 0.5 to $11.3 \%$ for $37.5 \%$ of simvastatin drugs, $30.0 \%$ of atorvastatin drugs and $21.4 \%$ of rosuvastatin drugs. In 2014 the price dropped within $0.3-6 \%$ for 6 drugs of simvastatin ( $20.7 \%$ of the range), and only for one drug of atorvastatin and 2 drugs of rosuvastatin. The price increased in the vast majority of drugs of the statin group of the foreign production in 2014 , and it was significantly high for the statin group by $32 \%$, and for the number of medicines there was increase by $60 \%$ and even by $80 \%$. In 2015 the price for the most of the drugs mentioned had further increase (for $94.7 \%$ of simvastatin drugs, $81.8 \%$ of atorvastatin drugs and $85.7 \%$ of rosuvastatin drugs); it was more significant than in $2014-49.4 \%$. For the period of 2012-2015 the prices for statins of the foreign production grew by $101.4 \%$. It is almost 2.5 times higher than the prices for domestic products.

One of the main causes for increase in prices for medicines, as well as other products, was the growth rate of the U.S. dollar starting in mid-2014, and it continues to the present day. In addition, the sales of the domestic products occur mostly by one-twolevel marketing channels in contrast with foreign drugs, which are promoted by means of the multilevel distribution channels. However, despite the dependence on the dollar rate the rise in the price of the absolute majority of the foreign statin drugs was behind the changes of the exchange rate. Only for 6 drugs ( $3 \%$ of the range) the price was the same and even slightly exceeded the dollar rate increase.

The price of the medicine, of course, significantly affects its availability, but the coefficient of the solvency adequacy (Ca.s) gives more complete idea of the possi- bility of using one or another drug in clinical practice. The low value of this coefficient provides the drug availability and guarantees its sales in low solvency of the population $[2,5,6]$.

The dynamics of Ca.s for statin drugs in the period from 2012 to 2015 is given in Fig. 2 and Table. The slight decrease of the value of Ca.s of 2013 for all INN statins changed by its rise in 2014, and it reduced the availability of statin drugs for the general population. In 2015 availability of foreign drugs of simvastatin and atorvastatin became even smaller. It was indicated by increase of the value of Ca.s. For the domestic drugs of simvastatin and atorvastatin, and import drugs of rosuvastatin the value of Ca.s decreased as compared to 2014, but did not reach the level of 2013. Despite the negative dynamics of the coefficient of the solvency adequacy all domestic statin drugs without exception remain highly available to the consumer until now (Table).

With the high probability it can be assumed that increase in the price of drugs and increase of the coefficient of the solvency adequacy can lead to reduction of the consumption of statin drugs. This, in turn, will reduce the possibilities of the primary and secondary prevention and create conditions for increasing the probability of cardiovascular accidents in patients 


\section{Distribution of statin drugs in accordance with the categories of availability by the coefficient of the solvency adequacy}

\begin{tabular}{|c|c|c|c|c|c|c|}
\hline MNN & Manufacturer & Categories of availability & $2012(\%)$ & $2013(\%)$ & $2014(\%)$ & $2015(\%)$ \\
\hline \multirow{4}{*}{ Simvastatin } & \multirow{2}{*}{ domestic } & highly available Ca.s $<5 \%$ & 77.8 & 100 & 100 & 100 \\
\hline & & medium available $<5 \%$ Ca.s $<15 \%$ & 22.2 & & & \\
\hline & \multirow{2}{*}{ import } & highly available Ca.s $<5 \%$ & 69.4 & 80.0 & 60.7 & 61.9 \\
\hline & & medium available $<5 \%$ Ca.s $<15 \%$ & 30.6 & 20.0 & 39.3 & 38.1 \\
\hline \multirow{4}{*}{ Atorvastatin } & domestic & highly available Ca.s $<5 \%$ & 100.0 & 100.0 & 100.0 & 100.0 \\
\hline & \multirow{3}{*}{ import } & Ca.s $<5 \%$ & 90.7 & 91.5 & 80.0 & 69.7 \\
\hline & & medium available $<5 \%$ Ca.s $<15 \%$ & 7.0 & 6.4 & 16.0 & 24.2 \\
\hline & & low available Ca.s > 15\% & 2.3 & 2.1 & 4.0 & 6.1 \\
\hline \multirow{3}{*}{ Rosuvastatin } & domestic & highly available Ca.s $<5 \%$ & & & 100.0 & 100.0 \\
\hline & \multirow{2}{*}{ import } & highly available Ca.s $<5 \%$ & 89.3 & 91.7 & 83.7 & 90.0 \\
\hline & & medium available $<5 \%$ Ca.s $<15 \%$ & 10.7 & 8.3 & 16.3 & 10.0 \\
\hline
\end{tabular}

with the risk factors, resulting in the increased morbidity and cardiovascular mortality. The research in this area is expedient to proceed.

\section{CONCLUSIONS}

1. There is an adequate range of statin drugs at the pharmaceutical market of Ukraine. During the period from 2012 to 2015 there was the positive dynamics of the market structure - increase in domestic drug production and its share in the market structure, appearance of new domestic manufacturers of statins.

2. Since 2014 there was increase in prices for the vast majority of drugs of the statin group of both domestic and foreign production - the average for the group was $42.1 \%$ and $101.4 \%$, respectively.

3 . The dynamics of the coefficient of the solvency adequacy indicates decrease in availability of statin drugs for the Ukrainian consumers in the period from 2012 to 2015. Under these conditions the possibility of the primary and secondary prevention of CVD is provided by high economic availability of domestic generic drugs, which range over the past four years has increased by $38 \%$. Measures in the healthcare system, contributing to increase availability and the amounts of statin use in Ukraine are needed.

\section{REFERENCES}

1. Гандзюк В.А. // Укр. кардіол. журн. - 2014. - №3. - С. 45-52.

2. Гудзенко О.П., Козицька К.І. // Укр. мед. альманах. - 2009. - №5. - С. 63-67.

3. Державна служба статистики Украӥни [Електронний ресурс] - Режим доступу до сайту: http://www.ukrstat.gov.ua/

4. Дубенко О.Е., Кульгейко В.В., Коваленко Д.П. и др. // Междунар. неврол. журн. - 2012. - №5 (51) - C. 162-168.

5. Котвицкая А.А., Лобова И.А. // Научные ведомости Белгородского государственного университета. Медицина. Фармация. - 2013. - №11 (154). - Вып. 22/2. - С. 32-38.

6. Немченко А.С., Ніколаєва Ю.Є. Аналіз коефіцієнту адекватності платоспроможності протипухлинних препаратів, що використовуються у хіміотерапії хронічних лейкозів // Менеджмент та маркетинг у складі сучасної економіки, науки, освіти, практики : матер. III міжнар. наук.-практ. Internet-конф., м. Харків, 26-27 берез. 2015 р. - Х. : НФаУ, 2015. - C. 310-311.

7. Программный комплекс «Аптека» компании «Морион» [Електронний ресурс] - Режим доступу до сайту: http://pharmbase.com.ua/poisk/.

8. Якушева Е.Н., Ушкалова Е.А. // Рос. мед.-биол. вестник им. акад. И.П.Павлова. - 2008. - №3. - С. 25-29.

9. Amarenco P., Labreuche J. // Lancet Neurol. - 2009. - Vol. 8. - P. 453-463.

10. Baigent C., Keech A., Kearney P.M. et al. // Lancet. - 2005. - Vol. 336 (9493). - P. 1267-1278.

11. Bellosta S., Ferri N., Paoletti R. et al. // Ann. Med. - 2000. - Vol. 32. - P. 164-176.

12. Efficacy and safety of LDL-lowering therapy among men and women: meta-analysis of individual data from 174000 participants in 27 randomised trials // Lancet. - 2015. - Vol. 385, Is. 9976. - P. 1397-1405.

13. Ford I., Murray H., McCowan C. et al. // Circulation. - 2016. - Vol. 133 (11). - P. 1073-1080. 
14. Fox K., Alonso Garcia M., Ardissino D. et al. // Eur. Heart. J. - 2006. - Vol. 27. - P. 1341-1381.

15. Guidelines for ATC classification and DDD assignment. 16th edition / WHO Collaborating Centre for Drug Statistics Methodology. - Oslo, 2012. - 284 p.

16. Gutierrez J., Ramirez G., Rundek T. et al. // Arch. Intern. Med. - 2012. - Vol. 172. - P. 909-919.

17. Heintjes E.M., Penning-van Beest F.J., Plat A.W. et al.//Pharmacotherapy. -2012. - Vol. 32, №7. - P. 631-641.

18. Introduction to drug utilization research / WHO International Working Group for Drug Statistics Methodology, WHO Collaborating Centre for Drug Statistics Methodology, WHO Collaborating Centre for Drug Utilization Research and Clinical Pharmacological Services // World Health Organization, 2003. - 48 p.

19. Jones P.H., Davidson M.H., Stain E.A. et al. // Am. J. Cardiol. - 2003. - Vol. 92, №2. - P. 152-160.

20. Law M.R., Wald N.J., Rudnicka A.R. // BMJ. - 2003. - Vol. 236. - P.1423-1426.

21. Luvai A., Mbagaya W., Hall A.S. et al. // Clin. Med. Insights Cardiol. - 2012. - Vol. 6. - P. 17-33.

22. Mills E.J., Rachlis B., Wu P. et al. // J. Am. Coll. Cardiol. - 2008. - Vol. 52 (22). - P. 1769-1781.

23. Mills E.J., Wu P., Chong G. et al. // Q. J. Med. - 2011. - Vol. 104. - P. 109-124.

24. Naci H., Brugts J., Ades T. // Circ. Cardiovasc. Qual. Outcomes. - 2013. - Vol. 6, №4. - P. 390-399.

25. OECD Health Statistics 2015 Definitions, Sources and Methods [Електронний ресурс] - Режим доcmyny до caŭmy: http://www.oecd.org/health/health-data.htm

26. Pedersen T.R. // Circ. Res. - 2016. - Vol. 118, №4. - P. 721-731.

27. Prospective Study Collaboration Blood cholesterol and vascular mortality by age sex and blood pressure: a meta-analysis of individual data from 61 prospective studies with 55000 vascular death // Lancet. 2007. - Vol. 370. - P. 1829-1833.

28. Reiner Ž., De Backer G., Fras Z. et al. // Atherosclerosis. - 2016. - Vol. 13 (246). - P. 243-250.

29. Roth L., Rombouts M., Schrijvers D.M. et al. // Vascul. Pharmacol. - 2016. - Jan 27. - P. 50-58.

30. Rubba P., Marotta G., Gentile M. // Vasc. Health Risk Manag. - 2009. - Vol. 5. - P. 343-352.

31. Taylor F., Ward K., Moore N. et al. // Cochrane Database Syst. Rev. - 2013. - Vol. 31. - №1. - P. 36.

32. Ward S., Lloyd J.M., Pandor A. et al. // Health Technol. Assess. - 2007. - Vol. 11 (14). - P. 1-160.

\title{
ФАРМАКОЕПІДЕМІОЛОГІЧНИЙ АНАЛІЗ: ДИНАМІКА ДОСТУПНОСТІ СТАТИНІВ В УКРАЇНІ Н.В.Бездітко, Л.В.Яковлєва, О.Я.Міщенко, І.В.Чинуш, Е.Л.Торянік Національний фармацевтичний університет
}

Ключові слова: фармакоекономіка; статини; фармацевтичний ринок; асортимент лікарських препаратів; динаміка; коефіцієнт адекватності платоспроможності

\begin{abstract}
Захворювання системи кровообігу - основна причина інвалідності та передчасної смерті в Украӥні. Великою кількістю РКД та мета-аналізів доведена висока профілактична ефективність застосування статинів для зниження ризику серцево-судинних захворювань (СС). Мета дослідження - аналіз динаміки вартості і економічної доступності лікарських препаратів статинів в Україні за період 2012-2015 рр. Динаміку цін на окремі препарати статинів визначали за даними системи «Фармакостандарт» компанії «Моріон». Для оцінки економічної доступності статинотерапії використовували показник адекватності платоспроможності. За результатами дослідження визначено, що на фармацевтичному ринку Украйни представлений достатній асортимент лікарських препаратів статинів. За період з 2012 р. по 2015 р. відзначається позитивна динаміка структури ринку - збільшення ЛП вітчизняного виробництва та їх частки в структурі ринку. 32014 р. відзначається зростання цін для абсолютної більшості лікарських препаратів групи статинів як вітчизняного, так і зарубіжного виробництва - в середньому по групі на 42,1\% і 101,4\% відповідно. Динаміка показника адекватності платоспроможності свідчить про зменшення економічної доступності препаратів статинів для українського споживача в період з 2012 р. по 2015 р. При цих умовах можливість первинної та вторинної статинопрофілактики ССЗ забезпечується високою економічною доступністю вітчизняних генеричних препаратів, асортимент яких за останні чотири роки виріс на 38\%. Потрібні заходи у системі охорони здоров'я, які б сприяли підвищенню доступності та об'ємів споживання статинів в Украӥні.
\end{abstract}

\section{ФАРМАКОЭПИДЕМИОЛОГИЧЕСКИЙ АНАЛИЗ: ДИНАМИКА ДОСТУПНОСТИ СТАТИНОВ В УКРАИНЕ Н.В.Бездетко, Л.В.Яковлева, О.Я.Мищенко, И.В.Чинуш, Э.Л.Торяник Национальный фармацевтический университет}

Ключевые слова: фармакоэкономика; статины; фармацевтический рынок; ассортимент лекарственных препаратов; динамика; показатель адекватности платежеспособности

\footnotetext{
Заболевания системы кровообращения - основная причина инвалидности и преждевременной смертности в Украине. Большим количеством РКИ и мета-анализов доказана высокая профилактическая эффективность применения статинов для снижения риска ССЗ. Цель исследования - анализ динамики стоимости и экономической доступ-
} 
ности лекарственных препаратов статинов в Украине в период 2012-2015 г2. Динамику цен на отдельные препараты статинов определяли по данным системы «Фармакостандарт» компании «Морион». Для оценки экономической доступности статинотерапии использовали показатель адекватности платежеспособности. По результатам исследования установлено, что на фармацевтическом рынке Украины представлен достаточный ассортимент лекарственных препаратов статинов. За период с 2012 г. по 2015 2. отмечается положительная динамика структуры рынка - увеличение ЛП отечественного производства и их доли в структуре рынка. С 2014 г. отмечается рост цен для абсолютного большинства лекарственных препаратов группы статинов как отечественного, так и зарубежного производства - в среднем по группе на 42,1\% и 101,4\% соответственно. Динамика показателя адекватности платежеспособности свидетельствует об уменьшении экономической доступности препаратов статинов для украинского потребителя в период с 2012 г. по 2015 г. При этих условиях возможность первичной и вторичной статинопрофилактики ССЗ обеспечивается высокой экономической доступностью отечественных дженериков, ассортимент которых за последние четыре года вырос на 38\%. Необходимы меры в системе охраны здоровья, способствующие повышению доступности и объемов потребления статинов в Украине.

Address for correspondence:

Received in 05.04.2016

4, Valentynivska str., Kharkiv, 61168, Ukraine.

Tel. (572) 65-88-95. E-mail: feknfau@ukr.net.

National University of Pharmacy 